\title{
WIDE BAND WAVEGUIDE SENSOR FOR MICROWAVE PULSE MEASUREMENT
}

\author{
Ž. Kancleris, P. Ragulis, R. Simniškis, and M. Dagys \\ Semiconductor Physics Institute, Center for Physical Science and Technology, A. Goštauto 11, LT-01108 Vilnius, Lithuania \\ E-mail: kancleris@pfi.lt
}

Received 18 February 2013; revised 12 March 2013; accepted 20 June 2013

\begin{abstract}
A wide band resistive sensor, the performance of which is based on electron heating effect in semiconductors, has been implemented in a double ridge waveguide WRD250 in a frequency range of 2.6-7.8 GHz. The dependences of the output signal on microwave pulse power and frequency response of the sensor were measured. The measured results of frequency response have been compared with the calculated ones obtained using a finite-difference time-domain method, and a reasonable agreement between them was found.
\end{abstract}

Keywords: microwave pulse power measurement, electromagnetic wave, double ridged (H-type) waveguide, frequency response, finite-difference time-domain method, resistive sensor

PACS: 07.07.Df, 41.20.-q, 07.50.-e, 07.57.Kp

\section{Introduction}

The growth of applications where high power microwave (HPM) pulses are used stimulates interest in sensors capable to measure them. One of the perspective devices is a resistive sensor (RS) [1], the performance of which is based on a hot electron phenomenon in semiconductors. The RS demonstrates some advantages when it is used for HPM pulse measurement. It measures HPM pulses directly, produces a high output signal, and exhibits an excellent longterm stability [1]. Since the RS is devoted to HPM pulse measurement the waveguide layout is usually used for its implementation. A sensing element (SE) of the sensor - the bulk resistor made from $n$ type Si with two contacts on the ends - is mounted in a waveguide. The electric field of the microwave pulse heats electrons in the SE, its resistance increases, and by measuring this resistance change the microwave pulse power in the waveguide is determined [1]]. Although the characteristics of a waveguide type RS were improved significantly devoting special attention to its frequency response [2, 3], the main disadvantage of the RS is a narrow frequency range limited by the pass-band of the rectangular waveguide.
In this paper, we used a double ridged waveguide shown in Fig. 1 to implement the SE of the resistive sensor. In comparison with a standard rectangular waveguide the double ridge waveguide more than twice widens the frequency range where the sensor can be used. The output characteristic of the sensor has been measured and compared with the calculated one using a finite-difference time-domain (FDTD) method [4].

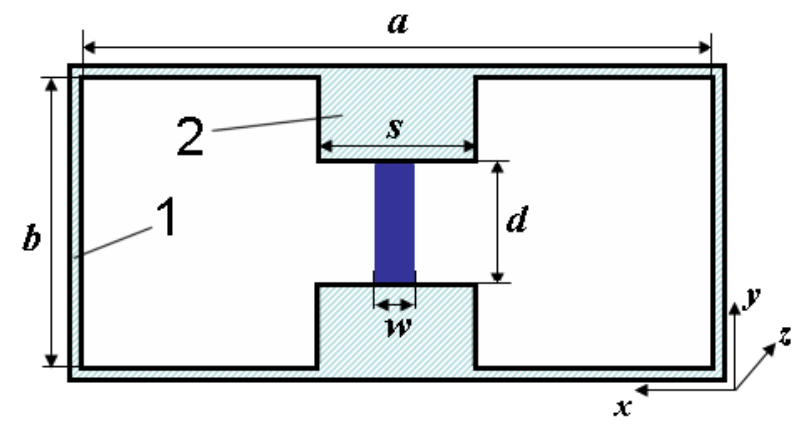

Fig. 1. Cross-sectional view of a double ridged waveguide with a sensing element of the RS covering the gap region: 1 waveguide wall, 2 metal ridge. The dimension of the sample in the wave propagation direction is $l$. 


\section{Sensor's layout}

A cross-sectional view of the double ridged waveguide is shown in Fig. 1. Comparing it with a rectangular waveguide, it is seen that additional metal ridges are inserted. The region of the waveguide between metal ridges is usually named a gap region whereas side regions are named troughs. The parameters of the double ridged waveguide WRD250 are collected in Table. In the Table I, dimensions of the waveguide, lowest and highest passing frequencies, cutoff frequency, and the maximum pulse power are presented. It is seen that the ratio $f_{\max } /$ $f_{\min }=3$ is characteristic of the double ridged waveguide, whereas for the rectangular waveguide this ratio is roughly 1.5 . Thus, by mounting the SE in a double ridged waveguide the RS operating frequency range can be significantly widened. Due to a smaller distance between metal surfaces in the gap region, the smaller maximum pulse power can be transmitted through it but according to the last column of the Table it is still significant.

The SE is inserted between metal ridges covering the entire gap region. Its height $h$ corresponds to $d$, the width of it is denoted as $w$, and $l$ stands for its length in a wave propagation direction. In our previous paper [4] we have considered such a sensor, and the average electric field strength in it has been calculated using the FDTD method. The following requirements have been formulated for the $\mathrm{n}$-Si sample that can serve as the SE: the SE should not cause considerable reflections in the waveguide, hence the value of a voltage standing wave ratio (VSWR) has been set at $<1.5$; the DC resistance of the RS should not exceed $1 \mathrm{k} \Omega$ enabling the measurement of microsecond duration microwave pulses; the frequency response of the RS in the waveguide's frequency band should be as flat as possible. It was found that the optimal sensor [4] should be made from $10 \Omega \mathrm{cm}$ specific resistance material with cross-sectional dimensions $w \times l=1 \times 1 \mathrm{~mm}^{2}$. Its calculated sensitivity variation within the waveguide's frequency range was $\pm 10.4 \%$, VSWR $<1.36$, and DC resistance was $400 \Omega$. The sensing elements with such parameters have been manufactured and mounted in the double ridged waveguide. Three pieces of the RS have been tested experimentally.

\section{Sensitivity and measurement set-up}

Under the influence of a strong electric field, the resistance of the SE increases. In a so-called warm electron region [1], a relative resistance change $\Delta R / R$ linearly depends on pulse power $P$ propagating in a waveguide. Therefore, the sensitivity of the RS can be expressed in the following way [ [4]:

$$
\zeta=\frac{\Delta R / R}{P}=\frac{U_{\mathrm{S}}}{U_{0} P} .
$$

where $U_{\mathrm{S}}$ is an output signal from the sensor measured in a linear region, and $U_{0}$ is a DC voltage fall on the SE. When writing the right side of (1), it was assumed that the output signal from the sensor is measured with a high input resistance device.

The measurements of the dependence of the RS output signal on pulse power propagating in the waveguide have been performed using magnetron generators in $\mathrm{S}(2.75 \mathrm{GHz})$ and $\mathrm{C}(5.7 \mathrm{GHz})$ frequency bands. The set-up of measurements is shown in Fig. 2. Actually two set-ups with different cross-sectional sizes of the rectangular waveguide windows were used in the experiments. Waveguide WR284 $\left(a \times b=73 \times 34 \mathrm{~mm}^{2}\right)$ was employed in the case of the S band, and waveguide WR187 $\left(a \times b=48 \times 22 \mathrm{~mm}^{2}\right)$ was employed for experiments in the $\mathrm{C}$ band. The RS was connected directly to the magnetron generator via transition from the rectangular to the double ridged waveguide T. Pulse duration was $4 \mu$ s and repetition rate was $25 \mathrm{~Hz}$. The reference RS in a rectangular waveguide was connected to the main port via a directional coupler. It controls pulse power in the main waveguide. By changing pulse power in the main port with the help of a precise attenuator $A$, the dependence of the output signal on the pulse power was measured using the oscilloscope TDS520A. The RS was fed by a current source keeping $10 \mathrm{~V}$ voltage drop on the SE. The measurements have been performed with and without an additional amplifier, the amplification of which was $K=10$.

Table I. Parameters of waveguide WRD250.

\begin{tabular}{c|c|c|c|c|c|c|c}
\hline$a, \mathrm{~mm}$ & $b, \mathrm{~mm}$ & $s, \mathrm{~mm}$ & $d, \mathrm{~mm}$ & $f_{\min }-f_{\max }, \mathrm{GHz}$ & $f_{\max } / f_{\min }$ & $f_{\mathcal{c}^{\prime}}, \mathrm{GHz}$ & $P_{\max }, \mathrm{kW}$ \\
\hline 42.0 & 18.2 & 11.2 & 3.8 & $2.60-7.80$ & 3.0 & 1.985 & 120 \\
\hline
\end{tabular}




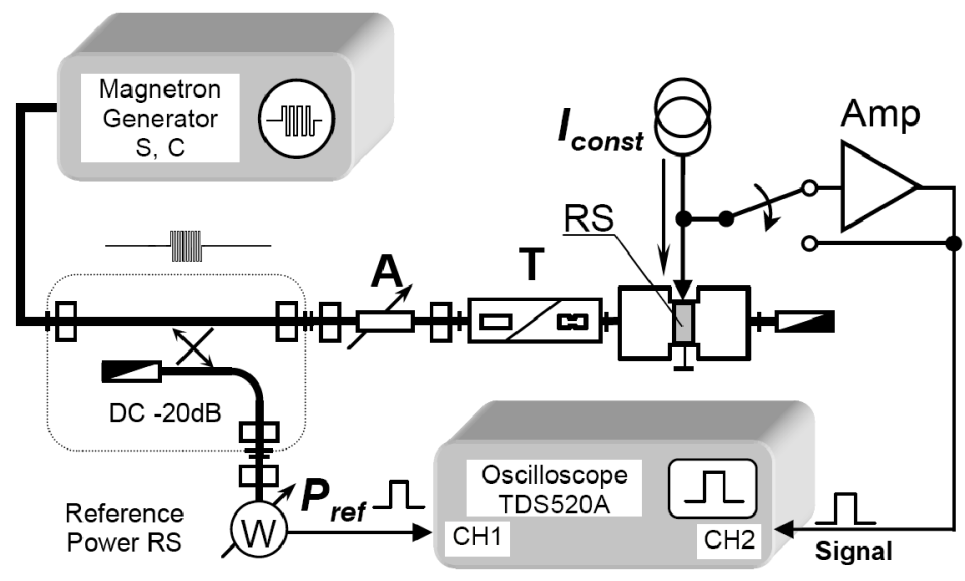

Fig. 2. Measurement set-up using high power microwave sources in $\mathrm{S}$ and $\mathrm{C}$ frequency bands: $A$ precise attenuator, $T$ transition from the rectangular to the double ridge waveguide, Amp additional pulse amplifier, $W$ reference $\mathrm{RS}$ in a rectangular waveguide, and $R S$ sensor under test.

It is well known [1] that in a wide range of the microwave pulse power, the dependence of $\Delta R / R$ on $P$ can be approximated by the second order polynomial in the following way:

$$
P=A \frac{\Delta R}{R}+B\left(\frac{\Delta R}{R}\right)^{2},
$$

where the coefficients $A$ and $B$ are determined by fitting the experimentally measured dependence of $\Delta R / R$ on $P$ with (2). In the linear region, $\Delta R / R<<1$ and the influence of the second term in (2) is negligible. Therefore, by comparing (2) with (1) one can see that $\zeta=A^{-1}$.

To measure the frequency response of the RS, a low power tunable microwave source producing roughly $200 \mathrm{~mW}$ average power was used. The meander modulated microwave signal was employed allowing to significantly increase measurement sensitivity [5]. As in a previous case, two set-ups with a different cross-sectional size of the waveguide window were used with the RS connected via transitions from the rectangular to the double ridged waveguide. The measurement set-up, in general, was similar to that shown in Fig. 2. Instead of the magnetron generator the tunable microwave source was connected to the rectangular waveguide with the help of a coaxial to rectangular waveguide adaptor. The microwave power supplied to the RS was measured using an average power sensor from Rhode \& Schwarz and the output signal from the RS was measured using a lock-in amplifier. The modulation frequency of a microwave signal has been chosen high enough $(10 \mathrm{kHz})$ to avoid additional resistance modulation due to lattice heating. On the SE, a $10 \mathrm{~V}$ voltage drop was applied. In this case the sensitivity of the RS can be related with an output signal $U_{\mathrm{m}}$ measured with a lock-in amplifier in the following way [5]:

$$
\zeta=\frac{\pi U_{\mathrm{m}}}{\sqrt{2} U_{0} P} .
$$

Thus by measuring the output signal and power transmitted to the RS, the dependence of sensitivity on frequency was determined.

\section{Measurement results and discussion}

The measurement results using magnetron generators for one of the tested sensors are shown in Fig. 3. In the figure, the dependences of the relative resistance change on pulse power in the waveguide are presented. The measurements have been performed with $(K=10)$ and without $(K=1)$ an additional amplifier. The solid lines in Fig. 3 show a two-term approximation (2), from which the values of the parameters $A$ and $B$ were determined. It is seen that the used approximation fits well the measured results. The RS at a lower frequency is more sensitive than at a higher one. In a high power domain, the output characteristic of the RS was measured up to the twofold increase of its resistance. It is seen that the RS in a double ridged waveguide is able to measure pulse power from a few Watts up to a few tens of $\mathrm{kW}$. It should be pointed out that the measured characteristics of other manufactured RSs are sufficiently closer to each other in a low power limit demonstrating a larger difference at a high power level. The measured value of the VSRW was less than 1.4 within the sensor's frequency range. 


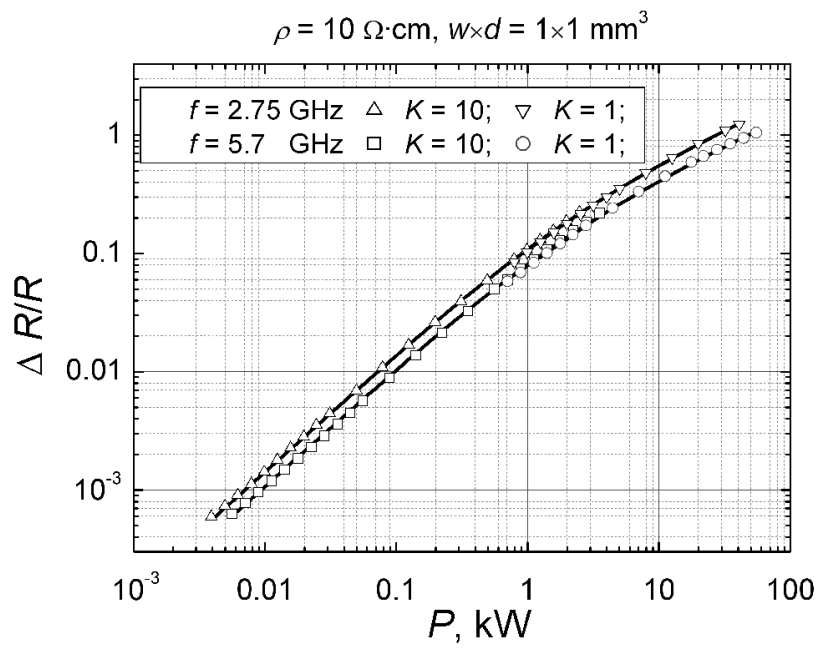

Fig. 3. Dependence of the relative resistance change on microwave pulse power for different frequencies Points show experimental results for two frequencies, solid lines correspond to the approximation (2).

The results of the measured frequency response of the RS together with calculation results [4] are shown in Fig. 4. Three different samples of the RS have been measured using the above-described meander modulated microwave signal and lock-in amplifier technique. The sensitivity values calculated according to (3) were averaged and are shown in Fig. 4 together with error bars. It is seen that a

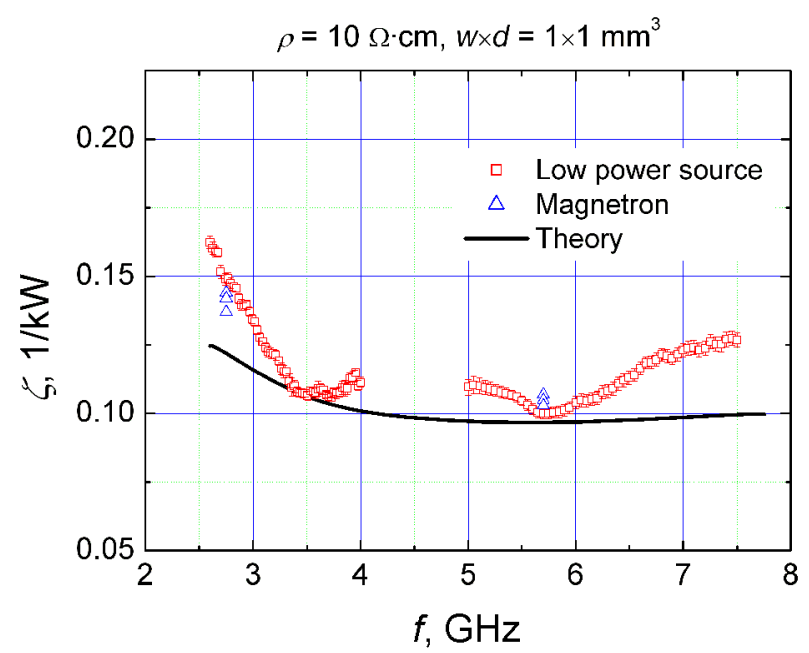

Fig. 4. Dependence of the sensitivity of the RS on frequency. Points show experimental results with a low power microwave source, triangles correspond to the sensitivity determined from experiments using magnetron generators, and a solid line demonstrates calculation results using the FDTD method [4]. small error is characteristic of the measured results supporting the fact mentioned earlier that the SEs with reproducible characteristics in a low power limit were manufactured. As follows from Fig. 4 the sensitivity determined from experiments with magnetron generators (triangles) fits well the results obtained using the meander modulated technique. By comparing the measured results with those calculated using the FDTD method one can see that a reasonable agreement between them was obtained. In comparison with the theoretical prediction, the measured results demonstrate a larger variation of sensitivity that is roughly $\pm 24 \%$. It should be pointed out that obtained discrepancy can be caused by the crudeness of the model used in FDTD calculation [4]: (i) fields in the double ridged waveguide were approximated by a single mode in a gap region and by infinite series of modes in troughs regions [6]; therefore, fields, in general, fail at the boundary between the two regions; (ii) in the calculations the dimensions of the waveguide were rounded up to the integer numbers of $\mathrm{mm}$; (iii) a sharp edge of the metal ridge was modelled in calculations, whereas it is rounded in the waveguide used for the SE mounting. Although the measured variation of the sensitivity of the RSs in the double ridged waveguide is larger than expected, their good reproducibility and increased frequency range are promising features for the application of the proposed sensors in HPM experiments.

\section{Conclusions}

The sensor permitting measurements of microwave pulses in the double ridged waveguide was implemented; its output characteristic and the dependence of its sensitivity on frequency were measured. A reasonable agreement between measured and calculated results of sensitivity was observed. The obtained variation of sensitivity of $\pm 24 \%$ of the RS appears to be good enough having in mind a wide frequency range of the sensor. It seems that the developed sensor could find its application in working together with a wide band horn antenna for the measurement of the microwave electric field strength in free space.

\section{Acknowledgements}

This research was funded by a grant MIP-092/2011 from the Research Council of Lithuania. 


\section{References}

[1] M. Dagys, Ž. Kancleris, R. Simniškis, E. Schamiloglu, and F.J. Agee, Resistive sensor: Device for high-power microwave pulse measurement, IEEE. Antenn. Propag. Mag. 43, 64-79 (2001).

[2] Ž. Kancleris, R. Simniškis, M. Dagys, and V. Tamošiūnas, High power millimetre wave pulse sensor for W-band, IET Microw. Antenn. Propag. 1, 757-762 (2007).

[3] Ž. Kancleris, R. Simniškis, M. Dagys, and $\mathrm{V}$. Tamošiūnas, X-band resistive sensor for high power microwave pulse measurement with flat frequency response, Electron. Lett. 44, 1143-1144 (2008).

[4] Ž. Kancleris and P. Ragulis, Interaction of semiconductor sample with $\mathrm{TE}_{10}$ mode in double ridged waveguide, Lith. J. Phys. 52, 1-9 (2012).

[5] V. Dienys, Ž. Kancleris, and Z. Martūnas, Warm Electrons, ed. J. Požela (Mokslas, Vilnius, 1983) [in Russian].

[6] J. Helszajn, Ridge waveguides and passive microwave components, IEE Electromagnetic Wave Series, Vol. 49, eds. P.G.B. Claricoats and E.V. Jull (The Institution of Engineering and Technology, London, 2000).

\title{
PLATAUS DAŽNIŲ RUOŽO BANGOLAIDINIS JUTIKLIS MIKROBANGŲ IMPULSAMS MATUOTI
}

\author{
Ž. Kancleris, P. Ragulis, R. Simniškis, M. Dagys \\ Fiziniu ir technologijos mokslu centro Puslaidininkiu fizikos institutas, Vilnius, Lietuva
}

\begin{abstract}
Santrauka
Ankstesniame mūsų darbe [何, pasinaudoję baigtinių skirtumų laiko skalëje metodu, išsprendème optimizacijos uždavinị ir nustateme jutiklio, patalpinto $\mathrm{H}$ tipo bangolaidyje, elektrofizikinius parametrus (jutiklio matmenis, savitąji laidumą) - kad jutiklio dažninè charakteristika turètų mažiausią netolygumą, stovinčios bangos koeficientas nuo jutiklio neviršytų 1,5 ir jutiklio varža neviršytu $1 \mathrm{k} \Omega$. Šiame darbe ištirtos tokio jutiklio jautrio priklausomybè nuo dažnio bei išèjimo signalo priklausomybė nuo mikrobangų impulso galios. Jutiklis buvo pagamintas iš $10 \Omega \mathrm{cm}$ savitosios varžos $\mathrm{n}$-Si, jo matmenys $-h \times w \times l=3,8 \times 1 \times 1 \mathrm{~mm}^{3}$, o varža $-400 \Omega$. Kaip parodyta 1 pav., strypelio pavidalo bandinys buvo talpinamas $\mathrm{H}$ tipo bangolaidžio centre tarp metalo strypų, praplečiančių bangolaidžio dažnių ruožą. Jutiklio signalo priklausomybè nuo mikrobangų impulso galios buvo išmatuota naudojant magnetroninius generatorius $\mathrm{S}(2.75 \mathrm{GHz})$ ir C $(5.7 \mathrm{GHz})$ dažnių ruožuose. Jutiklis prie atitinkamo dažnių ruožo stačiakampio
\end{abstract}

bangolaidžio buvo prijungiamas naudojant perejimus iš stačiakampio i $\mathrm{H}$ bangolaidị. Atlikti tyrimai parodé, kad tiriamasis jutiklis gali registruoti impulsus nuo kelių vatų iki kelių dešimčių $\mathrm{kW}$.

Dažninę jautrio priklausomybę išmatavome naudodami mažos galios perderinamą mikrobangų generatorių, kurio signalas buvo moduliuotas meandru. Tokia metodika leidžia signalo matavimui panaudoti selektyvuji stiprintuvą ir tokiu būdu gerokai padidinti matavimo jautrị. Išmatuota jutiklio jautrio priklausomybė nuo dažnio iš esmès sutapo su apskaičiuotąja. Išmatuotos ir apskaičiuotos priklausomybès šiek tiek blogiau sutapo žemesnių ir aukštesnių dažnių srityse. Eksperimentiškai nustatytas jautrio dažninès charakteristikos netolygumas sudare $\pm 24 \%$, tai yra visiškai priimtinas rezultatas turint omenyje platų matuojamajji dažnių ruožą. Mūsų manymu, sujungus sukurtaji jutiklị su plačiajuoste ruporine antena, jis galètu būti naudojamas elektrinio lauko stipriui atviroje erdveje nustatyti tiriant ịvairių objektų atsparumą mikrobangų spinduliuotei. 